УДК 551.3:691.223

ОРГАНИЗАЦИОННО-ТЕХНИЧЕСКИЕ РЕШЕНИЯ ПОВЫШЕНИЯ

ЭФФЕКТИВНОСТИ РАЗРАБОТКИ КАРЬЕРОВ ПЕСКА

В ЗОНАХ РАСПРОСТРАНЕНИЯ МНОГОЛЕТНЕМЕРЗЛЫХ ГРУНТОВ КРАЙНЕГО СЕВЕРА

Руденко А.С., Коркишко А.Н.

Строительный институт ФГБОУ ВО «Тюменский индустриальный университет», Тюмень, e-mail: rudenkoandrey76@mail.ru

\begin{abstract}
Предметом исследования в статье выступает технология разработки карьеров песка в условиях многолетнемерзлых грунтов Крайнего Севера. Целью настоящей статьи является определение и формирование отдельных организационно-технических решений, направленных на повышение эффективности работ по разработке карьеров песка в зонах расположения многолетнемерзлых грунтов арктических районов Крайнего Севера РФ. В процессе написания статьи были использованы методы наблюдения, обобщения и анализа. В статье проведен анализ проблемных вопросов существующей технологии разработки карьеров многолетнемерзлых грунтов. Для настоящего исследования авторами использованы материалы и данные, связанные с разработкой карьеров песка, расположенных в Ямало-Ненецком АО. Авторами предпринята попытка определить пути решения проблем и повышения эффективности разработки карьеров в условиях арктических районов Крайнего Севера. В рамках настоящего исследования авторами предложен способ оптимизации процесса организации водоотвода в круглогодичных карьерах со смешанными методами заготовки песка. Открытые водоотводные канавы и зумпф по периметру карьерного поля для летней заготовки песка предлагается формировать в зимний период, на завершающей стадии работ по буровзрывному рыхлению грунта Данное поэтапное распределение работ по формированию водоотводов может существенно сократить затраты на заготовку песка в летний период, а также более качественно организовать отвод поверхностных вод с территории карьерного поля, уменьшить риски затопления карьера. Включение данных организационно-технических решений в типовые технические задания на проектирование разработки карьеров может существенно оптимизировать процессы вовлечения песка в строительство объектов Крайнего Севера.
\end{abstract}

Ключевые слова: Крайний Север, многолетнемерзлые грунты, карьер, буровзрывные работы, разработка, зумпф, водоотводные канавы

\title{
ORGANIZATIONAL AND TECHNICAL SOLUTIONS TO STRENGTHENING THE EFFICIENCY OF SAND QUARRIES IN THE ZONE OF PERMAFROST SOIL IN THE FAR NORTH
}

\author{
Rudenko A.S., Korkishko A.N. \\ Construction Institute Federal State Budget Educational Institution of Higher Education \\ «Industrial University of Tyumen»,Tyumen, e-mail: rudenkoandrey76@mail.ru
}

\begin{abstract}
The article deals with the technology of sand quarrying in the context of permafrost soil in the Far North. The aim of the article is to define and form particular organizational and technical solutions which can strengthen the efficiency of sand quarries in the zone of permafrost soil in the Far North of the Russian Federation. Methods of observation, summarization and analysis were used in the process of writing the article. The article analyses problems of the present technology of permafrost soil quarrying. Much attention is given to an attempt of finding the ways to solve problems and to strengthen the efficiency of quarrying in the context of arctic areas of the Far North. For this research authors used data connected with sand quarrying in Yamalo-Nenets Autonomous Okrug. Authors of the article offer the way of optimizing the construction of the drainage system in year-round quarries with mixed methods of sand storage. Open drainage ditches and a dibhole on the perimeter of the quarrying field for summer sand storage are offered to be formed in winter during the final stage of drilling-and-blasting loosening the soils. These series of phased works to form drains can really reduce sand storage expenses in summer and organize better surface water drainage, reduce risks of submerging. The inclusion of these organizational and technical solutions in the standard design specifications for quarry development can significantly optimize the processes of involving sand in the construction of objects in the Far North.
\end{abstract}

Keywords: Far North, permafrost soil, quarry, drilling-and-blasting operations, exploitation, dibhole, drainage ditches

В настоящее время идет активный процесс освоения арктических регионов Крайнего Севера Российской Федерации. В арктические регионы России идет вложение огромных государственных и частных инвестиций. Основными сферами инвестиций являются проекты, направленные на развитие транспортной инфраструктуры, а также связанные с разработкой различных полезных ископаемых. Эти проекты требуют строительства очень большого количества самых разнообразных производственных объектов, что в свою очередь создает массу технологических и логистических вызовов. Особенно много проблем и вопросов возникает в связи с выполнением строитель- 
ных работ на многолетнемерзлых грунтах и необходимостью вовлечения этих грунтов в качестве строительных материалов.

Цель исследования: определение и формирование отдельных организационно-технических решений, направленных на повышение эффективности работ по разработке карьеров песка в зонах расположения многолетнемерзлых грунтов Крайнего Севера РФ.

\section{Материалы и методы исследования}

В рамках процесса реализации данного исследования авторами использованы методы наблюдения, анализа, эксперимента, a также обобщения фактических данных и наработок, полученных в результате практической работы по разработке карьеров песка и вовлечения многолетнемерзлых грунтов в строительное производство в арктических регионах Крайнего Севера.

\section{Результаты исследования и их обсуждения}

Для того чтобы перейти к рассмотрению основного вопроса нашей статьи, полагаем необходимым определить, что же, собственно, представляют собой многолетнемерзлые грунты.

Пункт 3.19 Межгосударственного стандарта ГОСТ 25100-2011 (введен в действие Приказом Федерального агентства по технологическому регулированию и метрологии № 190-СТ от 12.07.2012 г.), дает следующее определение мерзлого грунта - это грунт, имеющий отрицательную температуру, содержащий в своем составе видимые ледяные включения и (или) лед-цемент и характеризующиеся криогенными структурными связями.

Многолетнемерзлый грунт - грунт, находящийся в мерзлом состоянии постоянно в течение трех и более лет.

Сезонномерзлый грунт - грунт, находящийся в мерзлом состоянии периодически, в течение холодного сезона.

Термин введён в литературу в 1927 г. М.И. Сумгиным, основателем советской школы мерзлотоведения, в его работе «Вечная мерзлота почвы в пределах СССР», но в 1950-х гг. этот термин подвергся серьёзной критике и в современной научной литературе употребляется редко (чаще используется в научно-популярной), сейчас в основном используется термин - многолетнемерзлые грунты [1, с. 76].

Под многолетнемерзлыми грунтами (вечной мерзлотой) следует понимать толщи мерзлых горных пород, не оттаивающие в течение времени от нескольких лет до десятков и сотен тысяч лет. Продолжительность существования вечной мерзлоты, т.е. подземного оледенения, соизмерима с отрезками геологического времени.

На процесс и сроки возникновения многолетнемерзлых грунтов (криолитозоны, вечной мерзлоты) существуют различные точки зрения. Одни исследователи полагают, что вечная мерзлота сформировалась 10-15 тыс. лет назад, в период последнего сильного похолодания климата на Земле, что ее привело к оледенению ее поверхности в ряде регионов (ледниковый период). Другие исследователи полагают, что многолетнемерзлые толщи в криолитозоне, т.е. в области вечной мерзлоты, являются наследием климата, существовавшего сотни тысяч лет назад [2, с. 28-30].

В данной статье авторы не ставят перед собой задачу раскрыть истинные причины возникновения многолетнемерзлых грунтов, а попытаются определить эффективные способы вовлечения многолетнемерзлых грунтов в строительный процесс в районах Крайнего Севера.

Итак, мерзлой породой, грунтом или почвой называется такая порода, грунт или почва, температура которых ниже $0{ }^{\circ} \mathrm{C}$ и содержит лед. Поэтому к мерзлым породам естественно относить все породы, содержащие лед, и включать в них и крупные массы подземного льда, рассматривая последние как мономинеральную мерзлую горную породу. Лед в мерзлой породе рассматривается как породообразующий минерал. Своеобразие льда как породообразующего минерала подчеркивается динамическими изменениями его свойств в зависимости от температуры, давления и других факторов. По длительности существования мерзлого состояния пород принято разделять понятие «мерзлые породы» на три вида:

1. Кратковременномерзлые породы (часы, сутки).

2. Сезонномерзлые породы (месяцы).

3. Многолетнемерзлые породы (годы, сотни и тысячи лет).

Между этими категориями мерзлых пород могут быть промежуточные формы и взаимные переходы. Так, например, сезонномёрзлая порода может не протаять в течение лета и просуществовать несколько лет. Такие формы мерзлой породы называются «перелетками».

Зона сплошной мерзлоты характеризуется мощностями мёрзлых толщ от 500 и более до 300 м и самыми низкими температу- 
рами от $-10^{\circ} \mathrm{C}$ и ниже. Островная мерзлота характеризуется малыми мощностями вечномёрзлых пород от нескольких десятков метров до нескольких метров и температурами, близкими к $0^{\circ} \mathrm{C}[2$, с. 34-35].

В России южная граница распространения многолетнемерзлых пород, начинаясь на северной половине Кольского полуострова, протягивается к устью Мезени, затем к широтному колену Печоры и опускается вдоль западного склона Урала южнее $64^{\circ}$ с.ш. В Западной Сибири южная граница проходит по северному широтному отрезку Оби, поднимаясь к северу по долине Оби и опускаясь к югу вдоль долины Енисея. Ниже устья Подкаменной Тунгуски граница резко поворачивает на юг, уходя по правому берегу Енисея за пределы России в горные районы Монголии и Китая. На востоке России южная граница распространения мерзлых толщ огибает горные хребты вдоль Амура и на Камчатке.

В России территорию вечномерзлых грунтов делят на три зоны: сплошную; прерывистую (с таликами); островную. Сплошная мерзлота занимает крайний север Сибири, мощность мерзлой толщи сотни метров, температура грунтов минус $7-12^{\circ} \mathrm{C}$. Зона с таликами располагается южнее. Отдельные участки зоны представляют собой талые грунты; мощность мерзлых толщ 20-60 м при температуре $0,2-2^{\circ} \mathrm{C}$. Зона островной мерзлоты занимает территорию юга Сибири; мерзлые грунты встречаются в виде отдельных участков; мощность толщ 10-30 м; температура от 0 до $-0,3^{\circ} \mathrm{C}[3$, с. $4-6]$.

Существуют различные оценки площадей многолетнемерзлых грунтов на территории Российской Федерации. Так, например, А.А. Вакулин в своей работе «Основы геокриологии» указывает, что площадь распространения многолетнемерзлых толщ горных пород в настоящее время составляет $25 \%$ суши земного шара и примерно $65 \%$ площади России [2, с. 7].

В.В. Пендин, В.О. Подборская и Т.П. Дубина в «Мерзлотоведении» утверждают, что площадь распространения многолетнемерзлых грунтов составляет $25 \%$ всей суши земного шара и около $60 \%$ площади РФ [4, с. 4].

Т.Я. Емельянова и В.В. Крамаренко в своей работе «Практикум по мерзлотоведению» определяют, что площадь распространения многолетнемерзлых пород в пределах России составляет 47\% (примерно 10 млн кв. км) территории [3, с. 4].

Соответственно, вне зависимости от критериев, из которых в своих оценках исходили исследователи, в любом случае, Россия имеет не менее восьми с половиной девяти миллионов квадратных километров многолетнемерзлых грунтов, расположенных в основном на северо-востоке страны. Колоссальная территория. По факту она может быть существенно больше.

Это, безусловно, только усиливает необходимость тщательного изучения важнейших факторов инженерно-геологических условий разработки многолетнемерзлых грунтов в северных и восточных районах России. Особенно учитывая то обстоятельство, что значительная часть месторождений полезных ископаемых, которыми обладает Российская Федерация, уже разрабатываемых или еще планируемых к разработке в перспективе, преимущественно находятся на севере и северо-востоке РФ, в зонах многолетнемерзлых грунтов Крайнего Севера.

Состоянию вечной мерзлоты подвержены все виды грунтов. Грунты скального класса занимают незначительное место. Основную массу мерзлых толщ составляют дисперсные грунты (супеси, суглинки, глины, пески и т.д.) [5, с. 223].

Специфичность многолетнемерзлых грунтов заключается в том, что в них содержится лед, в зависимости от разновидности грунта до $90 \%$. При повышении температуры выше $0{ }^{\circ} \mathrm{C}$ мерзлый грунт оттаивает. При этом происходит выделение значительных объемов талых вод. По льдистости за счет видимых ледяных включений грунты подразделяют согласно табл. 1. Льдистость грунта за счет видимых ледяных включений $i$, д. е., - это отношение объема содержащихся в нем видимых ледяных включений к объему мерзлого грунта.

Таблица 1

Классификация мерзлых грунтов по льдистости [5, с. 224-225]

\begin{tabular}{|c|c|c|}
\hline $\begin{array}{c}\text { Разновидность } \\
\text { грунтов }\end{array}$ & \multicolumn{2}{|c|}{$\begin{array}{c}\text { Льдистость за счет видимых } \\
\text { ледяных включений, } i, \text {, д.е. }\end{array}$} \\
\cline { 2 - 3 } & $\begin{array}{c}\text { Скальные } \\
\text { и полускальные } \\
\text { грунты }\end{array}$ & $\begin{array}{c}\text { Дисперсные } \\
\text { грунты }\end{array}$ \\
\hline Слабольдистый & $<0,01$ & $<0,20$ \\
\hline Льдистый & $0,01-0,05$ & $0,20-0,40$ \\
\hline Сильнольдистый & $>0,05$ & $0,40-0,60$ \\
\hline Очень льдистый & - & $0,60-0,90$ \\
\hline
\end{tabular}

Таким образом, в дисперсных грунтах, к которым в том числе относится и песчаный грунт, содержание льда, т.е. воды 
в твердом агрегатном состоянии, составляет не менее $20 \%$.

ГОСТ 25100-2011 Грунты. Классификация п. 3.28 дает следующее определение Песчаного грунта, - песчаный грунт (песок) - это несвязный минеральный грунт с массой частиц размером 0,05-2 мм более $50 \%$ и числом пластичности - $1 \%$.

Песок - это основной строительный материал, который применяется при выполнении строительных работ. Именно песок используется для устройства насыпей автомобильных дорог и производственных площадок различного назначения. Определенно можно утверждать, что без песка необходимых объемов и качества добыча других полезных ископаемых в районах Крайнего Севера невозможна. Поэтому песок и его заготовка требуют к себе особого внимания. В строительстве характеристики и свойства песка имеют особое значение. Одной из наиболее существенных характеристик физико-механических свойств песка является влажность песка. Такая величина оказывает особое влияние на рабочий процесс вовлечения песка в строительстве. Поэтому перед использованием материала при сооружении зданий обязательно требуется знать, какое количество воды в его составе. Установленные данные влияют на процентный состав бетонных растворов, а также определяют пригодность сыпучей породы для строительных работ.

Влажность грунта характеризуют степенью насыщения грунта водой и определяют отношением массы воды в грунте к массе твердых частиц грунта. В зависимости от влажности, грунты подразделяют на:

- маловлажные (до $5 \%$ ),

- влажные (до 30\%),

- насыщенные водой (>30\%).

Одним из основных вопросов, требующих решения для эффективной разработки карьеров и добыче песка в летний период, является своевременная организация водоотведения и понижения уровня грунтовых вод (п. 6.2.10 СП 48.13330.2011).

Недостаточное внимание к осушению карьеров приводит к нарушению нормального технологического процесса их разработки и заготовки полезных ископаемых, а также формированию крупных оползневых деформаций. При этом снижается производительность карьера по заготовке песка, сама заготовка осложняется постоянными рисками подтопления разрабатываемых площадей, подтопление карьерного поля ведет к снижению объемов заготавли- ваемого песка. Для понимания объема воды, образующейся в пределах карьерного поля только от протаивания многолетнемерзлых грунтов, можно указать следующее. При исходных данных влажности песка около $30 \%$, в ходе летней заготовки песка путем многократного перемещения оттаявших слоев грунта в валы бульдозерами с последующей их экскавацией, происходит осушка песка до показателей по влажности, близким к оптимальным - 12-13\% [3, с. 7].

Соответственно при заготовке в карьере 1 млн м ${ }^{3}$ песка, обычная сезонная норма заготовки, образуется не менее 150-170 тыс. м $^{3}$ талых вод только от протаивания многолетнемерзлых грунтов. И это не учитывая естественных осадков, например, на Ямале, в годовом выражении составляют 300-350 мм, из них не менее $40 \%$ выпадает в течение летних месяцев, т.е. речь идет о сотнях тысяч кубических метров воды, подлежащей удалению с территории карьерного поля в течение летнего сезона заготовки.

В соответствии с требованиями нормативных актов вода, удаляемая с территории объектов горных работ (карьеров), должна сбрасываться в ближайший водоток или в место, исключающее возможность ее обратного проникновения через трещины, провалы или водопроницаемые породы в выработки и заболачивание прилегающих территорий. Запрещается производить сброс (сток) вод в отвалы. Для обеспечения устойчивости откосов горных выработок и отвалов, снижения влажности разрабатываемых и вскрышных пород, создания безопасных условий работы горного и транспортного оборудования в проекте должны предусматриваться меры по осушению территории производства работ и защите от поверхностных вод и атмосферных осадков [6, с. 114.].

В этой связи, для обеспечения полноценной разработки песчаных карьеров, необходимо в процессе проектно-изыскательских работ выполнять гидрогеологические исследования способов и схем осушения карьеров, причем центральное место должны занимать следующие взаимосвязанные вопросы:

1) систематизация многолетнемерзлых песчаных месторождений, разрабатываемых открытым способом, по гидрогеологическим условиям;

2) оценка зависимости способов и схем осушения от технологии ведения открытых горных работ; 
3) анализ технико-экономических показателей на осушение карьеров.

В то же время необходимо отметить, что устройство неоправданно сложных систем осушения ведет к резкому увеличению себестоимости добычи основного строительного материала при обустройстве месторождения и численности трудящихся, занятых в сфере осушения. Кроме того, необходимо отметить, что получаемые при разведке месторождений материалы гидрогеологических исследований зачастую являются недостаточно полными и качественными, особенно в свете обоснования систем осушения и охраны геологической среды при водопонижении на карьерах. Что в свою очередь побуждает нас искать оптимальные способы минимизации связанных с разработкой карьеров песка рисков.

Традиционно в проектах по разработке карьеров в летний период (сухоройным способом) в качестве основного решения по организации водоотвода предусматривается устройство водоотводных грунтовых канав, отвод воды из карьеров происходит по естественным уклонам рельефа.

Для устройства водоотводных канав в проектно-сметной документации закладываются работы и средства. Работы по устройству водоотводных канав требуют времени, технических и людских ресурсов, усилий подрядчиков и затраты средств заказчика. При этом необходимо отметить, что далеко не все карьеры предполагают наличие естественных уклонов рельефа для водоотведения.

В зимний период времени вопрос водоотведения в карьерах на Крайнем Севере обычно не стоит, поэтому технические решения проектов заготовки песка в карьерах в зимний период не содержат никаких технических решений по выполнению мероприятий для водоотведения. Однако учитывая непрерывность процесса обустройства месторождений в условиях многолетнемерзлых грунтов Крайнего Севера, сжатые сроки реализации строительных проектов объекты капитального строительства и постоянную потребность в песке, заготовка песка фактически идет в круглогодичном режиме, в том числе и в летний период. При этом сам процесс заготовки песка в летний период является достаточно затратным, в том числе и за счет мероприятий по водоотведению. С учетом данных обстоятельств, а также в целях оптимизации и сроков производственных процессов, связанных с заготовкой песка, мероприятия по водоотведению необходимо предусма- тривать в рамках единого процесса разработки карьеров еще на фазе зимней разработки (заготовки) песка.

Анализируя результат межсезонных опытно-производственных работ, выполненных при разработке многолетнемерзлых грунтов в процессе добычи песка как основного строительного материала для обеспечения бесперебойного круглогодичного удовлетворения потребностей инженерной подготовки объектов промыслов - можно констатировать, что, на наш взгляд, оптимальным решением вышеуказанных задач является применение механизированного способа разработки грунта методом буровзрывного рыхления (БВР), выполняемого преимущественно в период наличия устойчивых отрицательных температур воздуха. При этом методе взорванный грунт перемещают бульдозерами в валы, после чего экскаваторами грузят в автосамосвалы и вывозят на объекты строительства, с одновременным устройством траншейных дренажей по периметру карьерного поля, которые необходимо располагать выше уровня, аккумулирующего воду грунтового сооружения, так называемого «зумпфа». По нашему мнению, наиболее оптимальным для проведения БВР при разработке грунтов в ЯНАО является взрывчатый материал типа «Граммонит 79/21».

Зумпф - это выемка, создаваемая, как правило, при горной разработке и используемая в основном для приема гидросмесей, воды при перекачивании их насосами. На карьерах зумпф используется не только для временного аккумулирования гидросмеси, поступающей из забоев, но и для образования ее из горной массы и воды (рис. 1) [7, с. 610].

Водоотводные канавы и зумпфы - это традиционные технические решения, которые повсеместно применяются для организации водоотвода (водоотлива) поверхностных и талых вод с территории карьерного поля. Суть идеи оптимизации процессов водоотведения состоит в устройстве дренажных водоотводных канав с зумпфом по периметру карьерного поля для осуществления водоотвода (водоотлива) в летний период, еще на фазе выполнения буровзрывных работ в зимний период, в рамках работ по разработке (заготовке) песка методом буровзрывного рыхления.

Разработка карьеров методом БВР осуществляется ярусами. Высота (мощность) яруса составляет в среднем 3-4 м. Разработка каждого яруса начинается с проходки по периметру карьерного поля открытой водоотводной траншеи (рис. 2). 


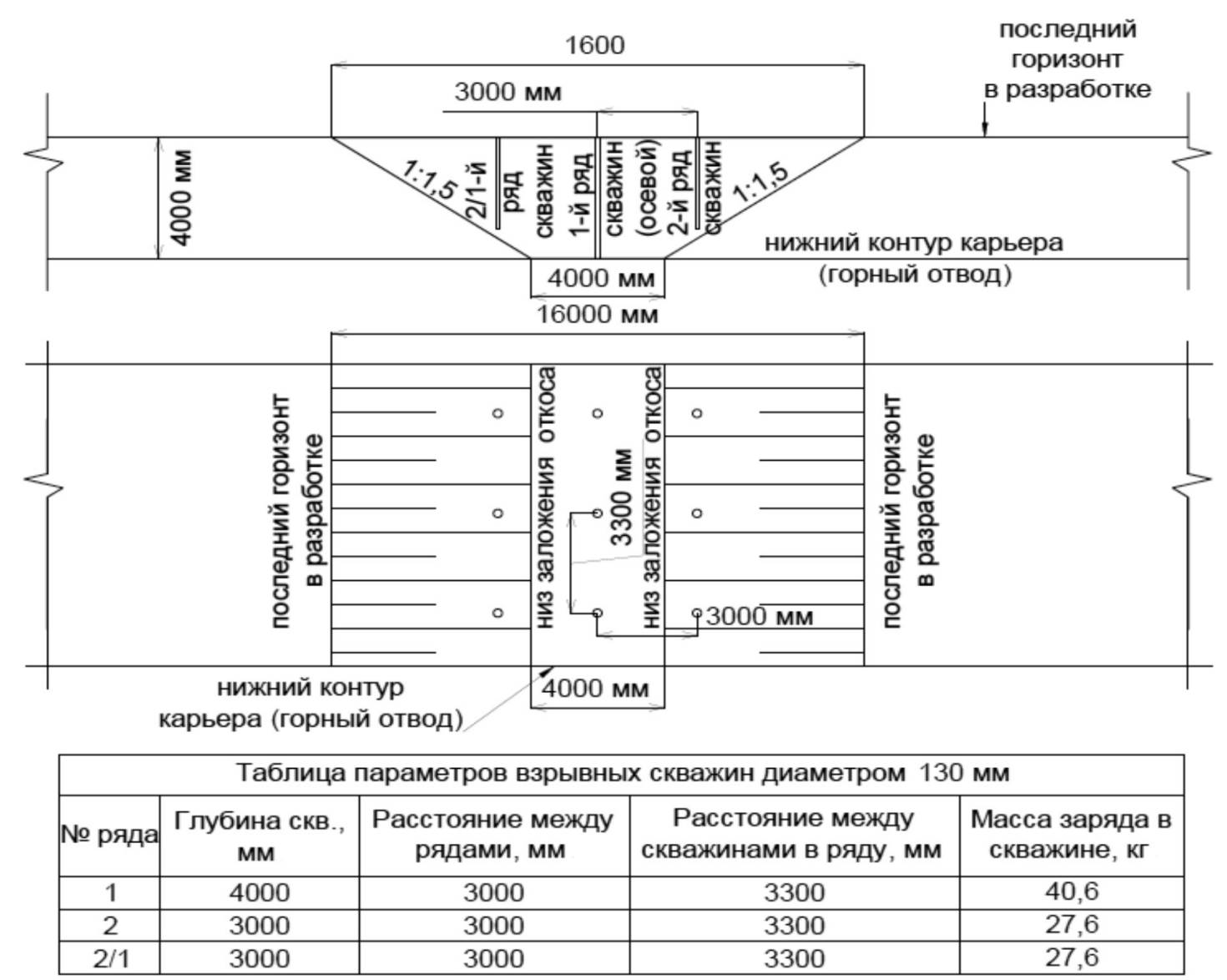

Рис. 1. Устройство «зумпф».

Разработка заключительного горизонта песка у нижнего контура карьера.

План расположения взрывных скважин

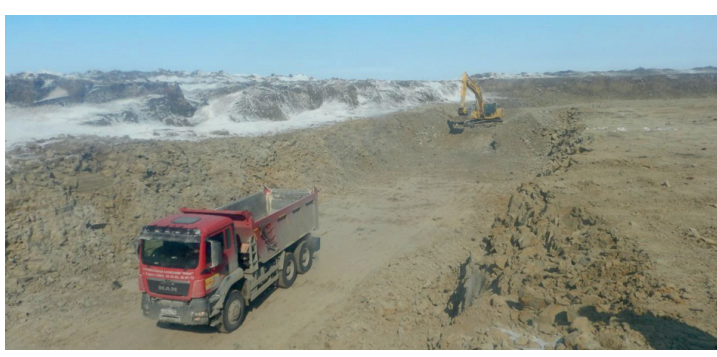

Рис. 2. Формирование водоотводной траншеи в проиессе заготовки песка методом БВР

Уклон траншеи принимается противоположным направлению выезда из карьеpa, зумпф формируется в нижней точке открытой траншеи. Водоприемный зумпф для сбора фильтрующей воды формируется в нижней точке траншеи. Площадки

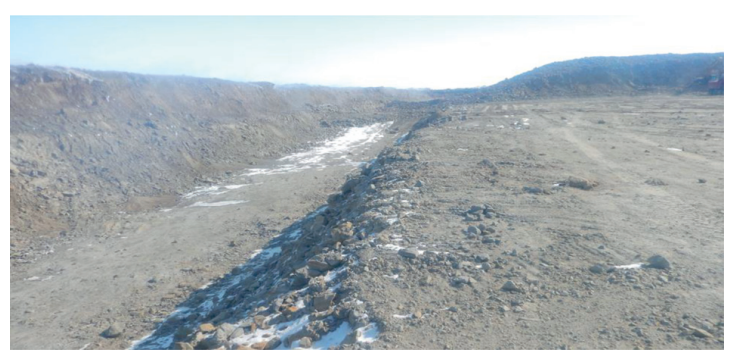

Рис. 3. Открытая водоотводная траншея по периметру карьерного поля

для установки насосов для откачки воды устанавливаются вблизи зумпфа у верхней бровки траншеи, при этом сами насосы для водоотлива устанавливаются уже после наступления положительных температур. По мере разработки карьера положение 
зумпфа и водоотводных канав по периметру карьерного поля меняется при разработке каждого следующего яруса (рис. 3).

Такая технология позволяет даже в случае внеплановой приостановки работ по разработке карьера иметь возможность для организации водоотвода/водоотлива до начала летней заготовки. При этом мы можем в значительной степени сократить расходы на устройство водоотводных канав (водоотлива) в летний период, так как значительная их часть будет выполнена в зимний период, в процессе заготовки песка методом БВР, с соответствующим отнесением затрат на себестоимость заготовки песка БВР.

Учитывая необходимость комплексного подхода в организации водоотведения в карьерах, в проектах на разработку карьеров следует предусматривать поэтапное выполнение запроектированной системы водоотвода. Для выполнения вышеозначенных условий, в Технических заданиях и проектных решениях по разработке карьеров, предусматривающих выполнение работ по разработке (заготовке) песка, в течение двух и более сезонов, с использованием различных технологий заготовки, необходимо изначально предусматривать работы по устройству водоотводных канав с зумп- фом в зимний период, в процессе финальной разработки БВР в сезоне. Организация и подготовка водоотвода из карьера должны опережать производственные процессы по добыче песка. Для успешного и оперативного обустройства водоотводных канав с зумпфом необходимо применить буровзрывные работы. Это особенно важно для обеспечения летней заготовки в карьерах, не обеспеченных свободным водостоком по уклонам рельефа поверхностных и талых вод, а также воды, выделяемой из грунта в процессе оттайки в результате воздействия солнечной радиации. При устройстве зумпфа для песка с влажностью до 20\% предлагаем принять во внимание угол естественного откоса грунта в траншеи равный отношению 1:1.5 (рис. 4).

При наличии более влажных грунтов в откосной части водоотвода необходимо предусмотреть заложение естественного откоса с учётом фактической влажности и формирования откоса за счет естественного оплывания. Устройство зумпфа с дренажными водоотводными канавами по периметру карьерного поля позволяет организовать водосбор и уменьшить риски затопления карьерного поля талыми и поверхностными водами (рис. 5).

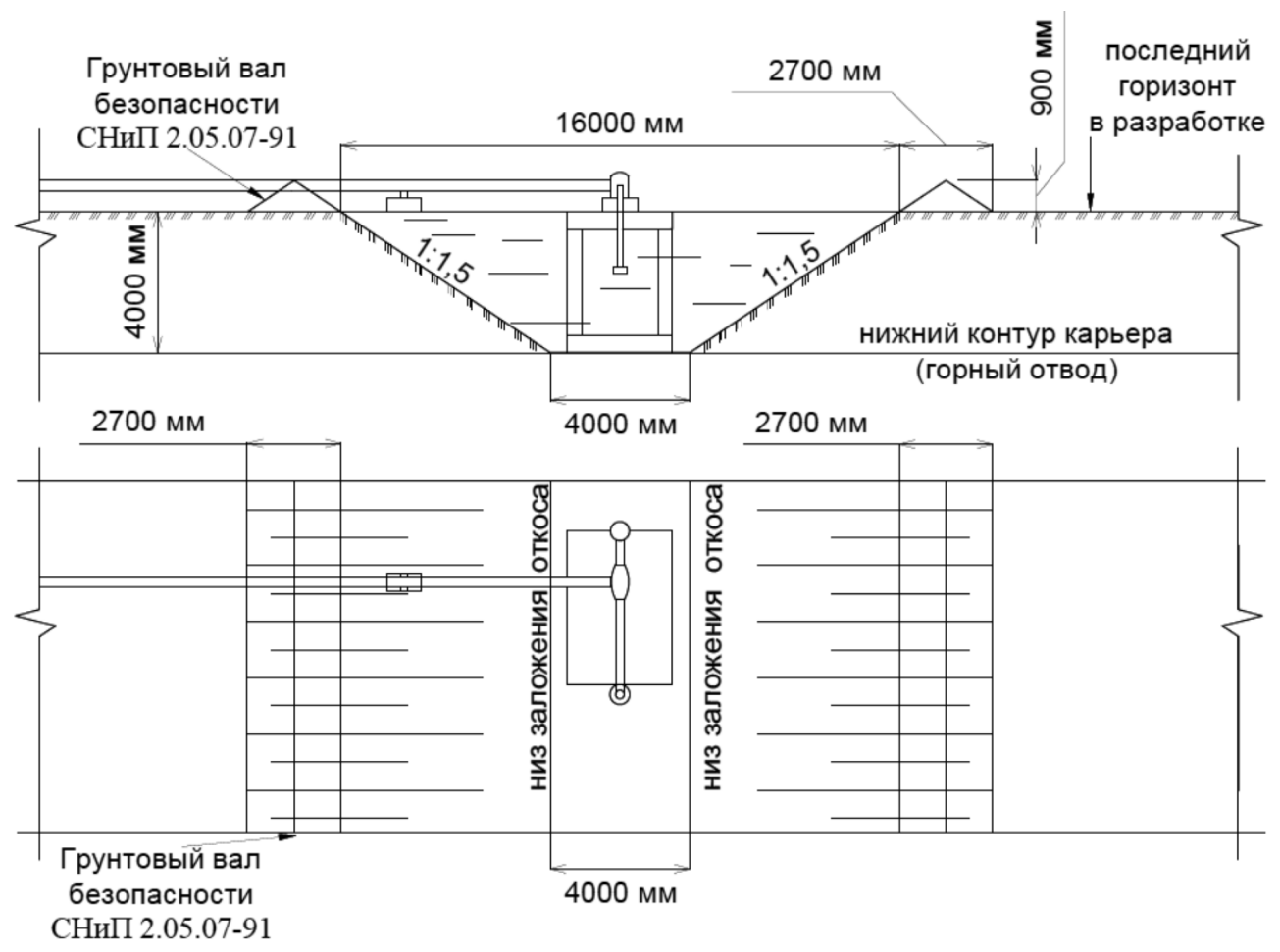

Рис. 4. Схема устройства зумпфа с водоотливом 


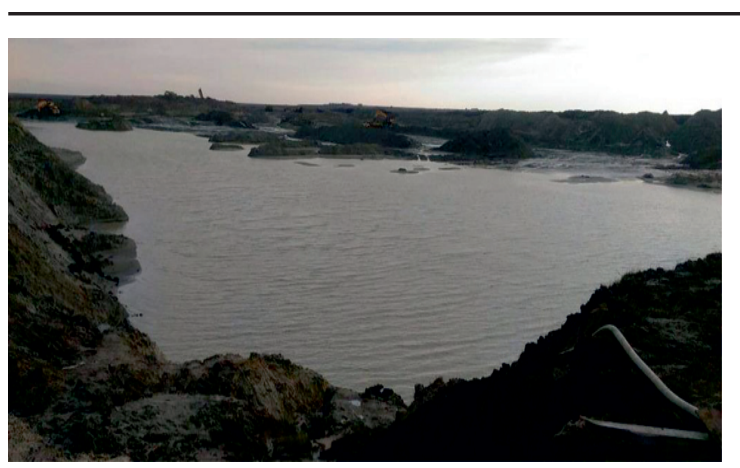

Рис. 5. Карьерное поле с зумпфом, но без водоотводных канав по периметру

По факту, кроме всего прочего, мы получаем дополнительный резервуap для сбора поверхностных (талых) вод. Что немаловажно, с учетом возможных технических неисправностей водоотливных систем и просчетов, при организации водоотвода (рис. 6).

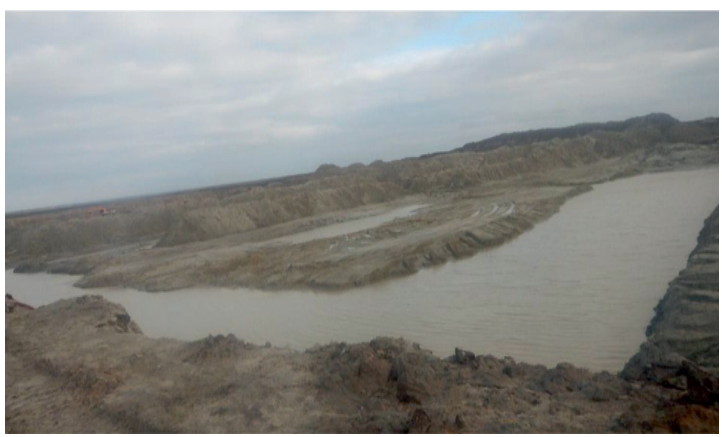

Рис. 6. Карьерное поле с зумпфом и водоотводными канавами по периметру, сформированными способом БВР в зимний период

Воду, собирающуюся в траншеях и канавах карьеров, необходимо отводить самотеком за пределы карьерного поля. В проектах систем защиты карьеров от поверхностных и талых вод необходимо предусматривать устройство насосных станций откачки воды непосредственно из карьерных выработок, когда невозможно или нецелесообразно отвести поступающую в них воду самотеком по естественным уклонам рельефа.

Основной водоприток в песчаных карьерах Крайнего Севера формируется в паводковый период за счет таяния снега, а также за счёт атмосферных осадков и оттаивания многолетнемерзлых грунтов от солнечной радиации. Соответственно, производительность используемых зумпфовых насосных санкций должна обеспечи- вать полное водоотведение поверхностных и талых вод за пределы карьера (разреза) с помощью водоотлива.

В соответствии с п. $6.9,6.37$ СП 103.13330.2012 зумпфовые насосные станции должны быть оборудованы не менее чем двумя насосными агрегатами - рабочим и резервным - и располагаться с учетом площади водосбора поверхностных вод и обеспечения минимальных затрат на водоотлив.

Для снижения концентрации взвешенных веществ также следует предусматривать отстаивание карьерных вод в отстойниках. Вместимость отстойника следует определять с учетом объема откачиваемых карьерных вод, требуемого времени отстоя и допускаемого сброса осветленных вод в водный объект, при этом время отстоя карьерных вод для достижения необходимого снижения концентрации взвешенных веществ следует определять опытным путем.

Важный вопрос - обеспечение безопасности работ в карьере. Для обеспечения безопасности при разработке карьеров необходимо соблюдать меры безопасности. В частности, по периметру водоотводных канав и зумпфа в связи с перепадом высот предлагается выполнять устройство ориентирующего грунтового вала безопасности по краям открытых водоотводных траншей и зумпфа. В нашем случае предлагается высота ориентирующего ограждающего вала равного 0,9 м. Работы по формированию вала можно выполнить перед началом летней заготовки за счет перемещения бульдозером оттаявшего песка по периметру зумпфа и водоотводных канав бульдозером. Либо на фазе проектирования предусмотреть замену защитного вала из грунта по периметру зумпфа сигнальным ограждением. Этот вопрос требует отдельной проработки, так как требует решения финансовых вопросов по оплате работ, связанных с обеспечением безопасности.

\section{Заключение}

Преимуществом устройства водоотводных канав и зумпфа для летней заготовки песка в карьерах на стадии БВР является их фактически нулевая себестоимость, так как данные работы производятся в рамках выполнения работ по заготовке песка в зимний период и не создают дополнительных издержек на фазе летней заготовки песка. Это позволяет экономить значительные финансовые и временные ресурсы, столь необходимые при реализации строительных проектов в условиях Крайнего Севера. 


\section{Список литературы / References}

1. Коркишко А.Н. Особенности разработки и экспертизы проектно-сметной документации на сухоройные карьеры песка в районах вечной мерзлоты для обустройства нефтяных и газовых месторождений // Инженерный вестник Дона. 2015. Т. 38. № 4 (38) [Электронный ресурс]. URL: ivdon.ru/ru/magazine/archive/n4y2015/3351 (дата обращения: 18.12.2019)

Korkishko A.N. Features of development and expertise of design and estimate documentation for dry sand quarries in permafrost areas for the development of oil and gas fields // Inzhenernyy vestnik Dona. 2015. Vol. 38. № 4 (38) [Electronic resource]. URL: ivdon.ru/ru/magazine/archive/n4y2015/3351 (date of access: 18.12.2019) (in Russian).

2. Вакулин А.А. Основы геокриологии. Тюмень: Изд Тюменского государственного университета, 2011. 220 с

Vakulin A.A. Fundamentals of Geocryology. Tyumen: Izd. Tyumenskogo gosudarstvennogo universiteta, 2011. $220 \mathrm{p}$ (in Russian).

3. Емельянова Т.Я., Крамаренко В.В. Практикум по мерзлотоведению. Томск: Изд. Томского политехнического университета, 2010. 120 с.

Emelyanova T.Ya., Kramarenko V.V. Workshop on permafrost. Tomsk: Izd. Tomskogo politekhnicheskogo universiteta, 2010. 120 p. (in Russian).
4. Пендин В.В., Подборская В.О., Дубина Т.П. Мерзлотоведение: учебное пособие. СПб.: Изд. Лань, 2017. 172 с.

Pendin V.V., Podborskaya V.O., Dubina T.P. Studies of permafrost rocks: Textbook. SPb.: Izd. Lan', 2017. 172 p. (in Russian).

5. Ананьев В.П., Потапов А.Д. Инженерная геология. М.: Высшая школа, 2002. 511 с.

Ananyev V.P., Potapov A.D. Engineering Geology. M.: Vysshaya shkola, 2002. 511 p. (in Russian).

6. Кравец К.В., Кекелия Г.Ж., Крижанивская Т.В., Набоков А.В. О некоторых характерных особенностях разработки сухоройных карьеров песка в криолитозоне для обустройства нефтегазовых месторождений // Инженерный вестник Дона. 2018. № 1 (48) [Электронный ресурс]. URL: http://www.ivdon.ru/ru/magazine/archive/n1y2018/4704 (дата обращения: 18.12.2019).

Kravets K.V., Kekelia G.Zh., Krizhanivskaya T.V., Nabokov A.V. on some characteristic features of the development of dry sand quarries in the cryolith zone for the development of oil and gas fields // Engineering Bulletin of the Don. 2018. No. 1 (48) [Electronic resource]. URL: http://www.ivdon.ru/ru/magazine/archive/ n1y2018/4704 (date of access: 18.12.2019) (in Russian).

7. Большая советская энциклопедия. М.: Советская энциклопедия, 1972. Т. 9. 624 с.

Great Soviet encyclopedia. M.: Sovetskaya entsiklopediya, 1972. Vol. 9. 624 p. (in Russian). 